\title{
写真撮影による下顎運動測定法
}

\author{
坂東 永一* 栗山 實** 河野 正司** \\ 中野 雅徳** 長谷川成男**
}

\section{Photographic Analysis of Mandibular Movement}

\author{
Eiichi Bando*, Minoru Kuriyama**, Shoji Kohno**, \\ Masanori Nakano**, Shigeo Hasegawa**
}

\section{I. 緒言}

下䫑運動の測定法の 1 つに写真計測を利用する方法が ある. 東京医科歯科大学第 2 歯科補緅学教室でも電気的 測定法 ${ }^{1 \sim 4)}$ は，その他 ${ }^{5,6)}$ の方法とともによく用いられて きた.

写真計測法には，まず佐久間》により開発されたマル チフラッシュ法がある.この方法は切歯点部前方に標点 用の突起を出し，そこに2 個の白い標点をつけ, シャッ ター開放でマルチフラッシュ光源によりガラス乾板上に この標点の運動軌跡を撮影するものである. 測定対象は 下顎の矢状面内運動であり， 2 点 2 次元測定とよべるも ので, 下顎上の任意の点の矢状面内運動を算出しうる. この方法により末次8) は Vertical Stop のない被験者の 下䫑運動，下額位について研究を行い，また河野9 は全 運動軸を発見した.

マルチフラッシュ法に加えて写真法に注古屋 ${ }^{10}$ 亿より 開発された，ミラーを用い2 方向からみた標点ランプの 運動を同時に 1 枚のポラロイドフィルムに撮影する方法 がある.この方法により古屋は頡関節症患者の切歯部の 3 次元運動について研究した. 中野11) はミラーとポラロ イドカメラを両側顆頭部にも追加設置することで，下顎 の 3 点 3 次元運動が記録可能なように改良して, 切歯路

* 徳岛大学㱖学部第 2 齿科補緅学教室

** 東京医科齿科大学歯学部第 2 歯科被学教室

* 2nd Prosthetic Dentistry, School of Dentistry, Tokushima University

** 2nd Department of Prosthodontics, School of Dentistry, Tokyo Medical and Dental University 昭和 54 年 8 月 31 日受付
と顆路の関係について研究した. さらに, 栗山12)の用い た方法では上䫑部および各カメラ部に標点を追加するこ とで，上䫑に対する下䫟の運動をより純粋に測定できる ようにして, 苗牙指導要素を種々に変化させたときの顆 路への影響を研究した.

この方法は, 下䇗の位置を立体的に絶対測定すること を可能としたもので, 写真計測法としては 1 つの完成形 に到達したものである. そこで本論文に拉いて，この研 究方法を中心として写真計測法による下頡運動測定の問 題点, 下䪽運動測定データの誤差, データ処理法につい て検討を加えた.

\section{II. 測定法について}

東京医科歯科大学第 2 歯科補緅学教室で写真計测法を 利用した下䫓運動に関する研究の一覧表を表 1 に示す. 佐久間により開発されたマルチフラッシュ法は 2 点 2 次 元計測であり，測定データは 4 個の座標值である.この うち 3 個が有效情報，1 個は午長情報である.

1959 年のこの研究により写真法による下䫑運動の解 析への道は拓かれたが，全運動軸の発見には電子計算機 の使用も可能となった約 10 年後の河野の研究までまた ねばならなかった．古屋はミラーを使用して豆電球の動 きを1枚のフィルム上に 2 方向から見た軌跡として撮影 できるような装置を製作して，枵页口腔機能に異常のある 被験者を主とする切歯点部の 3 次元運動について解析し た. 中野は両側顆頭部全運動軸上にさらに標点を追加し て， 3 台のカメラの測定データの同期をとることで 3 点 3 次元測定を可能にした. さらに, 栗山の用いた方法で は各フィルムの 4 隅に基準点を 撮影するために 12 個の 
表 1 写真計測法を利用して行われた下類運動の研究

\begin{tabular}{|c|c|c|c|c|c|c|c|}
\hline 研究者 & 発 表 & 研究方法 & 研究对象 & 標 & 测定 量 & 望たる & $\begin{array}{l}\text { 测定精度, } \\
\text { テー夕処理 }\end{array}$ \\
\hline $\begin{array}{l}\text { 佐久間 } \\
\text { 孔毅 }\end{array}$ & \begin{tabular}{|c|} 
口病誌 26 \\
$1511-1536$ \\
昭和 34 \\
1959 \\
\end{tabular} & $\begin{array}{l}\text { マルチフ } \\
\text { ラッシュ } \\
\text { 法 }\end{array}$ & $\begin{array}{l}\text { 矢状面内 } \\
\text { 限界連動 } \\
(2 \text { 点 } 2 \text { 次元 } \\
3 \text { 要妻 })\end{array}$ & $\begin{array}{l}\text { 切茵点部前方黑板に } 2 \text { 個の白点 } \\
\text { 頭部動摇監視用標点 } \\
\text { ミラーーで矢状面内運動を監視 }\end{array}$ & $\begin{array}{l}1 \text { 下顎位に } 4 \text { 座 } \\
\text { 標値 } \times \text { 約 } 80 \text { 下顎 } \\
\text { 位 } \times 10 \text { 人 }\end{array}$ & $\begin{array}{l}\text { 测定方法・解 } \\
\text { 析方法の開発 }\end{array}$ & $\begin{array}{l}\text { 切歯部0.1mm } \\
\text { 機械式卓上計 } \\
\text { 算器 }\end{array}$ \\
\hline $\begin{array}{l}\text { 末次 } \\
\text { 恒夫 }\end{array}$ & $\begin{array}{c}\text { 補緅誌 } 5 \\
131-169 \\
\text { 昭和36 } \\
1961\end{array}$ & $\begin{array}{l}\text { マルチフ } \\
\text { ラッシュ } \\
\text { 法 }\end{array}$ & $\begin{array}{l}\text { 矢状面内 } \\
\text { 限界運動 } \\
\text { 各種下顎位 }(2 \\
\text { 点2次元3要素) }\end{array}$ & $\begin{array}{l}\text { 切柴点部前方黑板に } 2 \text { 個の白点 } \\
\text { 側方偏位の少ない被験者を選択 }\end{array}$ & $4 \times 80 \times 12$ 人 & $\begin{array}{l}\text { 無歯頡者の切 } \\
\text { 歯点, 顆頭点 } \\
\text { 連動籍囲の明 } \\
\text { 示 }\end{array}$ & $\begin{array}{l}\text { 切菌部0.1一 } \\
0.5 \mathrm{~mm} \\
\text { 機械式卓上計 } \\
\text { 算器 }\end{array}$ \\
\hline $\begin{array}{l}\text { 河野 } \\
\text { 正司 }\end{array}$ & \begin{tabular}{|c|} 
補緅誌 12 \\
$350-380$ \\
昭和 43 \\
1968
\end{tabular} & $\begin{array}{l}\text { マルチフ } \\
\text { ラッシュ } \\
\text { 法 }\end{array}$ & $\begin{array}{l}\text { 矢状面内 } \\
\text { 限界運動 } \\
\text { 開 開 路 } \\
(2 \text { 点 } 2 \text { 次元 } \\
3 \text { 要絭 })\end{array}$ & 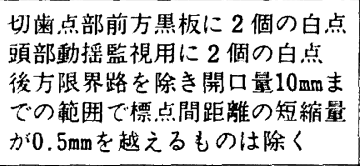 & $4 \times 50 \times 10$ 人 & $\begin{array}{l}\text { 全運動軸の発 } \\
\text { 見 }\end{array}$ & $\begin{array}{l}\text { 切菌部 } 0.1 \mathrm{~mm} \\
\text { 医用器材研究 } \\
\text { 所 } \\
\text { NEAC } 2101\end{array}$ \\
\hline $\begin{array}{l}\text { 古屋 } \\
\text { 良一 }\end{array}$ & \begin{tabular}{|c|} 
補綴誌 18 \\
$221-245$ \\
昭和 48 \\
1973
\end{tabular} & $\begin{array}{l}\text { ミラー組 } \\
\text { み合わせ } \\
\text { ポラロイ } \\
\text { ドカメラ } \\
1 \text { 台 }\end{array}$ & $\begin{array}{c}\text { 下顎切菌点部 } \\
\text { の限界運動路 } \\
(1 \text { 点 } 3 \text { 次元 } \\
3 \text { 要素 })\end{array}$ & $\begin{array}{l}\text { 下顎切歯点前方 } 40 \mathrm{~mm} \text { に豆電球を } \\
1 \text { 個 } \\
\text { 頻部動摇監視用 } 1 \text { 個 }\end{array}$ & $\begin{array}{l}(3+1) \times 150 \times \\
(30+40) \text { 人 }\end{array}$ & $\begin{array}{l}\text { 顎機能異常者 } \\
\text { の診断法の確 } \\
\text { 立 }\end{array}$ & $\begin{array}{l}0.1 \mathrm{~mm} \\
\text { 東大 HITAC } \\
8800 / 8700\end{array}$ \\
\hline $\begin{array}{l}\text { 中野 } \\
\text { 雅徳 }\end{array}$ & \begin{tabular}{|c|} 
補緅誌19 \\
$461-479$ \\
昭和50 \\
1975
\end{tabular} & $\begin{array}{l}\text { ミラー組 } \\
\text { み合わせ } \\
\text { ポラロイ } \\
\text { ドカメラ } \\
3 \text { 台 }\end{array}$ & $\begin{array}{l}\text { 歯牙接触滑走 } \\
\text { 運動 } \\
(3 \text { 点 } 3 \text { 次元 } \\
\quad 6 \text { 要素 })\end{array}$ & $\begin{array}{l}\text { 下顎阿側顆頭部及び切柬点部に } \\
\text { 計 } 3 \text { 個の豆球 } \\
\text { 頭部動摇監視用に } 1 \text { 個 }\end{array}$ & $\begin{array}{l}(3+1) \times 3 \times \\
6 \times 311\end{array}$ & $\begin{array}{l}\text { 切菊 Guide } の \\
\text { 算出法の確立 }\end{array}$ & $\begin{array}{l}\text { 読取部0.12mm } \\
\text { 東大 HITAC } \\
8800 / 8700\end{array}$ \\
\hline $\begin{array}{l}\text { 栗山 } \\
\text { 実 }\end{array}$ & \begin{tabular}{|c|} 
補経誌 23 \\
$126-147$ \\
昭和54 \\
1979
\end{tabular} & $\begin{array}{l}\text { ミラー組 } \\
\text { み合わせ } \\
\text { ポラロイ } \\
\text { ドカメラ } \\
3 \text { 台 }\end{array}$ & $\begin{array}{l}\text { 蒾牙接触消走 } \\
\text { 運動他 } \\
(3 \text { 点 } 3 \text { 次元 } \\
6 \text { 要素 })\end{array}$ & $\begin{array}{l}\text { 上顎基準用に } 9 \text { 個, フィルム基 } \\
\text { 準用に12個, 下顎に } 3 \text { 個の計 } 24 \\
\text { 個の豆球標点 }\end{array}$ & $\begin{array}{l}\{2 \text { 座標値 } \times 4 \text { 隅 } \\
+44 \text { 座標値 } \times(\text { 上 } \\
\text { 䫟 } 3 \text { 点十顎 } 1 \\
\text { 点 } \times 220 \text { 下顎位 })\} \\
\times 6 \text { 経路 } \times 3 \text { 力 } \\
\times \text { × } 5 \text { 人 }\end{array}$ & $\begin{array}{l}\text { 顆路の測定法 } \\
\text { の確立 }\end{array}$ & $\begin{array}{l}\text { 研究対象のす } \\
\text { だての部位に } \\
\text { おいて } 0.1 \mathrm{~mm} \\
\sim 0.25 \mathrm{~mm} \\
\text { 東大 HITAC } \\
\quad 8800 / 8700\end{array}$ \\
\hline
\end{tabular}

標点ランプと, 各フィルムに完全な上顎の動摇のデータ を得るために各 3 点計 9 個の標点ランプを追加して, 基 準となる咬頭嵌合位が失われても各フィルム間でのデー タが比較できるように，いいかえれば下顎位，下䫟運動 の絶対測定が可能なように改良した. これで写真計測法 としては一応完成した形となったわけであるが, 標点数 は 2 個加ら 4 個, 4 個から 24 個と等比級数的に増加し て, 写真法の限界に達した感がある. 実際, この方法に は 1 度に 24 個の標点ランプを使用しているので, 読み とるべきデータの数が多いこと，1枚のフィルムに数下 㖽位を撮影したときに各下顎位毎には頭部動摇を補正し きれないこともある. しかし，写真測定法には装置の作 製，実験が容易であり，また得られた記録が直接的に理 解できるという優れた面もあるので，今後はこのような 装置による場合でも光電変換等により自動測定をめざす ベきであろう.

中野, 栗山は顆頭部標点を全運動軸上に設置したが, これは生データをそのままで見る場合には見やすいとい う利点はあるが，作業側運動路は運動量が極端に小さく
なったり，あるいは後戻り運動 ${ }^{5,13)}$ 等で対応点を判別し 難くなる欠点むある. 任意の 3 点でのデータがあれば下 顎上の任意の場所の運動仕数学的に容易に求めることが できるので, 臨床用の検查機器の場合はともかく, 研究 用には運動範囲の大きい場所に標点を設圆する方が有利 であろう。

なお, 20 数年前の測定結果を見ると,これは写真測定 法に限ってこのことではないが，限界運動範囲等に最近 の結果とやや異なる点があるが，これはおそらく被験者 側の問題ではなく，われわれ研究者側の知識に基うく問 題であろう，測定装置の作製を含めて実験には下顎運動 に関する充分な基礎的知識が必要かと思う.

\section{III. 測定値の処理法について}

\section{2 次元テーータの重心基準剛体化処理法}

写真法で得られるデータは空間に，ある位直を占めて いる標点のある平面に対する座標値として得られる.

マルチフラッシュ法による 2 点 2 次元測定の場合, 図 


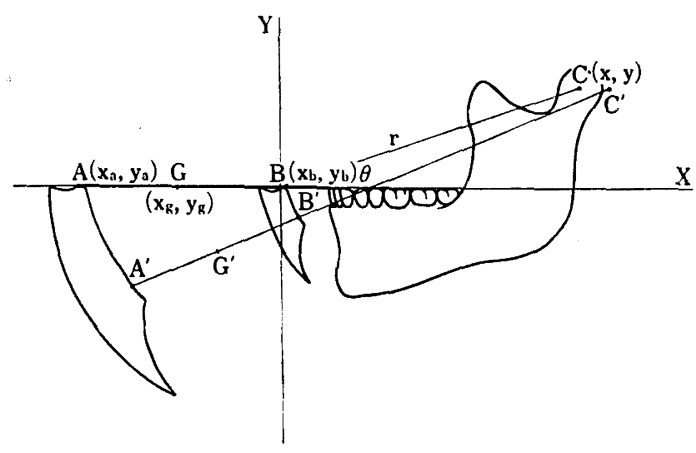

図 1 矢状面内下顥運動の測定法（佐久間，末次，河野）

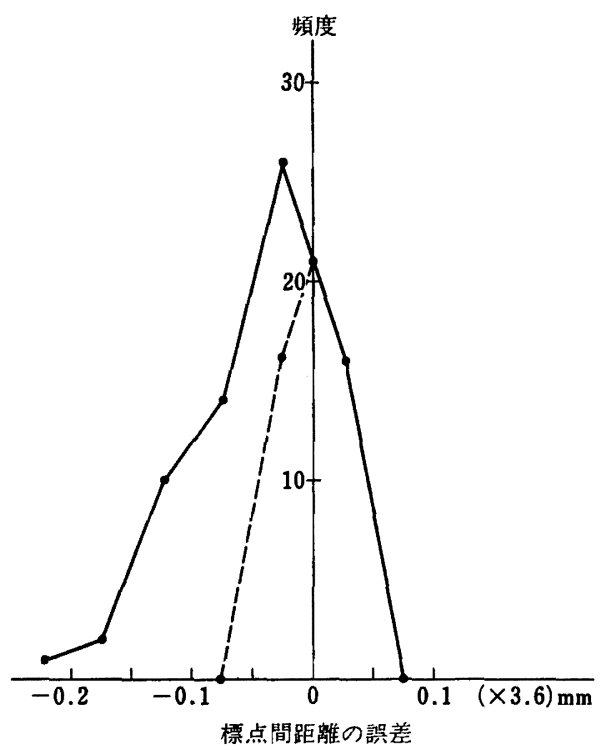

図 2 標点間距離についての刚体条件のくずれの例 (河野)

横軸のスケールは写真乾板上での值であり, 掫 影倍率は 1/3.6 であるので, 3.6 倍すれば実寸 となる. 負領域の䛇差は点線で表わす分布がほ ぼ計測誤差であり，他は生物学的に起因する誤 差と考えられる.

1 に示すようにデータとしては標点 A, B の矢状面内に 扔ける座標值 $\left(x_{a}, y_{a}\right),\left(x_{b}, y_{b}\right)$ の 4 つが得られる. ᄂ かし，これらの值から標点 $\mathrm{AB}$ 間距離を計算すると毎回 一定値になるわけではない.この原因は実験中に標点の ついているアルミ板標識がたわんで標点間距離が変わっ たと考えるより，测定值に誤差が含まれているためと考 えられ，その差より測定精度を知ることができる. 誤差 の原因の 1 つは被験者が焦点平面以外の運動 7 ,9) をする という生物学的な要因によるものであり, 他の 1 つは計

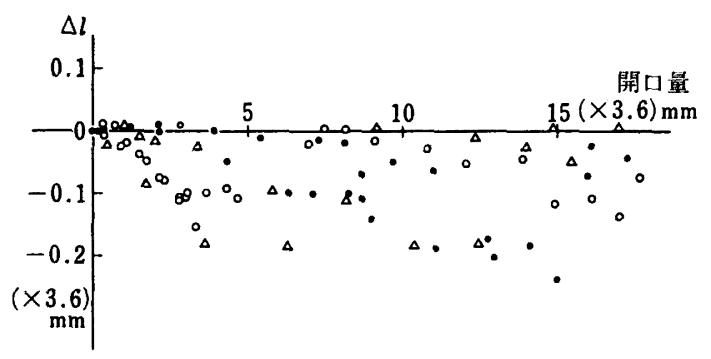

図 3 開口量と測定精度の例（河野）

: 後方限界運動路,

$\triangle:$ 開閉口運動路,

$\mathrm{O}:$ 前方滑走一開口運動路

測上のことに起因するものである，実際の例を河野9)の データについて示せば図 2 のようになる、誤差は真の標 点間距離に対して, 測定した標点間距離が短かくなり負 に分布するものがやや多くなり，標準偏差 $\sigma=0.324 \mathrm{~mm}$ である. 計測した標点間距離が短かくなる原因の大部分 は下嚬運動時に下顎が側方偏位して焦点平面から外れる ことにある.この要因を考えると,図 2 の点線で示すごと く，正の誤差を縦軸に対称に負にもとった分布が計測誤 差であり，その他のものが下䫑の側方偏位などに由来す る生物学的な誤差と推定できる.この標点間距離の誤差 $\Delta l$ と開口量との関係を求めると図 3 のようになり，一般 に咬頭嵌合位付近のデータでは精度が良くなる．またこ の $\Delta l$ と計測した下頡運動経路との関係をみると, 後方 限界運動や開閉運動では開口量が大きくなると $\Delta l$ も負 領域に比較的大きな值をとるようになり，下顎が開口と 共化側方偏位していることが推定できる．また前方滑走 運動路では上下顎前歯に指導される運動であるので, 前 歯部の咬合状態の影響を受けるためか開口量の小さな範 囲においても比較的大きな側方偏位が認められている.

このように観測値が剖体条件を満たさないことは稀れ てはないが，そのままで解析を進めるとか，モデル化あ るいはシュミレーションを行うと不都合なことが生じや すい. 2 点 2 次元のこの測定の場合, 4 個の観測值 $\left(x_{a}\right.$, $\left.y_{a}, x_{b}, y_{b}\right)$ が得られているとともに, 標点間距離は既 知の值で一定である.

そこで，いま 4 個の観測值に含まれている誤差の分布 型および大きさが等しい場合について検討してみる. 4 個の観測値 $\left(\mathrm{x}_{\mathrm{a}}, \mathrm{y}_{\mathrm{a}}\right),\left(\mathrm{x}_{\mathrm{b}}, \mathrm{y}_{\mathrm{b}}\right)$ に対する真の値を $\left(\mathrm{X}_{\mathrm{a}}\right.$, $\left.Y_{a}\right),\left(X_{b}, Y_{b}\right)$ としてそのときの誤差を $\pm e(e \geqq 0)$ と すれば 
$96-680$

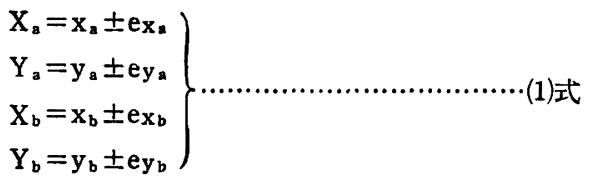

となる.

いま， A, B 両標点間の中点 $\mathrm{G}$ に注目して，その真の 座標値を $\left(X_{g}, Y_{g}\right)$, 上記の観測值から得られる座標値 を $\left(\mathrm{x}_{\mathrm{g}}, \mathrm{y}_{\mathrm{g}}\right)$ とすれば,

$$
\left.\begin{array}{l}
x_{g}=1 / 2\left(x_{a}+x_{b}\right) \\
y_{g}=1 / 2\left(y_{a}+y_{b}\right)
\end{array}\right\}
$$

となる.ここで 士 $\mathrm{ex}_{\mathrm{g}}, \pm \mathrm{e}_{\mathrm{g}}$ に注目すれば

$$
\left.\begin{array}{l} 
\pm e_{x_{z}}=1 / 2\left( \pm e_{x_{a}} \pm e_{x_{b}}\right) \\
\pm e_{y_{g}}=1 / 2\left( \pm e_{y_{a}} \pm e_{y_{b}}\right)
\end{array}\right\}
$$

となる. $\left| \pm \mathrm{ex}_{\mathrm{g}}\right|$ すなわち, $\mathrm{ex}_{\mathrm{g}}$ は $\mathrm{ex}_{\mathrm{a}}$ あるいは exb 大きい方より大きくなることはない. eyz についても同 様である，したがって，G点では標点部分より誤差の小 さい観測データが得られることになる．確率的には 2 個 の観測值の平均值であるので，諜差は $\mathrm{x}$ 方向， $\mathrm{y}$ 方向の それぞれについて $1 / \sqrt{2}$ の大きさになる. $\overline{\mathrm{AG}}, \overline{\mathrm{GB}}$ の 距離は既知の一定の值であるので，直線 $\mathrm{AB}$ 上に $\mathrm{G}$ を基 準にして逆に A，B の位置を求め直すことができる.こ のようにして求めた A, B の座標值はもとの，なまの観 測值より誤差の大きさがそれぞれ $1 / \sqrt{2}$ の大きさにな っている.

ここまでは各観測值に含まれている誤差の大きさは等 しいものとして議論を進めてきたが, 精度に差がある場 合にはそれぞれの観測値に重みをつけた，重みつきの重 心Gを求め同様の処理をすることができ，このような姏 理法を重心基淮剛体化処理と呼ぶことにする.

2 次元運動の場合, 運動の記述は基準座標系に対して 移動する座標系の原点の 移動 $\left(\mathrm{x}_{0}, \mathrm{y}_{0}\right)$ とそのまわりの 回転 $\theta$ の 3 つ要素で表すことができる.これに対して 観測值は 4 個あるので、ここに述べる重心基準剛体化処 理が可能となる. すなわち，4 個の観測值のうち任意の 3 個を選ぶことで数学的に下頡の位置は一義的に決まっ てくるが, 残りの 1 観測值を使って原点の移動に関する 誤差を確率的に小さくする処理法である. 座標軸の回転 $\theta$ に関しても，もちろん誤差は含まれているが， 2 標点 を結ぶ直線 $\mathrm{AB}$ の傾きを合理的な方法で修正することは できない，また，重心基準剛体化処理後のデータより計 算をすすめる場合は演算によって測定誤差を増大させる 危険性が少ない.

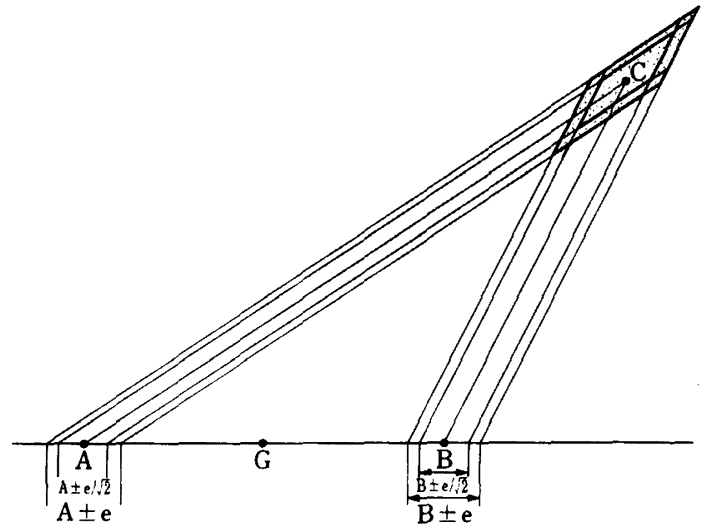

图 4 任意の点の運動算出における重心基淮用体化 処理による効果

2 点 $A ， B か ら$ 任意の点 C を推定した場合处 理によってCの誤差範围は 1/2 の面積となる.

処理の効果を図 4 によって説明するいま，観測すべ き 2 標点 $\mathrm{A}, \mathrm{B}$ があり， $\overline{\mathrm{AB}}$ 間の距離は一定で一直線上 を運動しているものとする．また，任意の点 Cは点 $A$ ， $\mathrm{B}$ を通り，直線 $\mathrm{AB}$ とそれぞれ一定の角をなす直線の交 点として定義されていて，その点の運動も知りたいもの とする (図 4 ). このとき $\mathrm{A}, \mathrm{B}$ の測定を行えば，それ ぞれに誤差を持つため, $\mathrm{A} \pm \mathrm{e}, \mathrm{B} \pm \mathrm{e}$ の範囲内のどこか

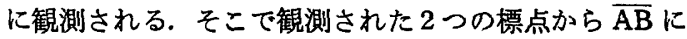
それぞれ一定の角度で 2 本の直線を引き，その交点 $\mathrm{C}$ 求めると，図中点 Cのまわりに示した大きな平行四辺形 のなかのどこかに位置することになる.これに対して重 心基準用体化処理を行うと誤差は確率的に小さくなり， $\mathrm{A}, \mathrm{B}$ の観測位置はそれぞれ $\mathrm{A} \pm 1 / \sqrt{2} \mathrm{e}, \mathrm{B} \pm 1 / \sqrt{2} \mathrm{e}$ の 籁囲内に求まり，Cは図中点 $\mathrm{C}$ のわりの小さい方の平 行四辺形の中に求まることになる. この大, 小両平行四 辺形の面積比は $2: 1$ になっている.

また,この 2 点 2 次元の解析において任意の点 $\mathrm{C} の$ 定 義を, $\mathrm{G}$ を一端とする直線 $\mathrm{AB}$ と一定の角をなす線分 GC の他端点と改めると，C 小さい平行四辺形の直線 $\mathrm{AB}$ と平行な方の対角線上に求まることになる.これに 対して点 $\mathrm{C}$ を生データの $\mathrm{A}$ また $\mathrm{B}$ からの線分の他端点 と定義すれば，大きい平行四辺形の対角線上に求まるこ とになる.この対角線の長さの比は $1 / \sqrt{2}: 1$ になって いる.

このような問題は純粋に解析幾何学的に解けばどのよ うな方法でも同じ正しい結果が得られるはずであるが, 観測值に誤差が含まれているため, 処理方法によっては 結果の精度にこのような差がでるのである. 


\section{3 次元データの重心基洀剛体化処理法}

重心基準㓮体化処理を 3 次元運動に適用してみる、下 影に 3 標点 $(P, Q, R)$ を設けそれぞれについて $(x, y, z)$ の座標値が得られ，各観測値の重みが（i, j, k) である とき, 重心 $\mathrm{G}\left(\mathrm{x}_{\mathrm{g}}, \mathrm{y}_{\mathrm{g}}, \mathrm{z}_{\mathrm{g}}\right)$ の值は

$$
\begin{aligned}
& x_{g}=\frac{i_{P} x_{P}+i_{Q} x_{Q}+i_{R} x_{R}}{i_{P}+i_{Q}+i_{R}} \\
& y_{g}=\frac{j_{P} y_{P}+j_{Q} y_{Q}+j_{R} y_{R}}{j_{P}+j_{Q}+j_{R}} \\
& z_{g}=-\frac{k_{P} z_{P}+k_{Q} z_{Q}+k_{R} z_{R}}{k_{P}+k_{Q}+k_{R}}
\end{aligned}
$$

となる. 重みがすべて 1.0 すなわち等しい場合，それぞ れの座標値に含まれる誤差は各標点の生のデータの誤差 の $1 / \sqrt{3}$ の大きさになる. 重心 $\mathrm{G}$ 呮差の空間的な大き さは $(1 / \sqrt{3})^{3} \fallingdotseq 1 / 5.2$ となる.この場合も得られた観測 值 9 個のうち, 少なくとも $\mathrm{P}, \mathrm{Q}, \mathrm{R}$ の要素を 1 個は含 む任意の 6 要素で下顥位は一義的に決まるので, 残りの 3 要素でより確からしい位直を求めることになる. 上顎 に対する下顎の座標系の原点の移動に関する 3 要素と各 軸のまわりの回転 3 要素のうち, 平面 $\mathrm{PQR}$ の空間的傾 きを合理的に修正する方法はないので，原点の移動に関 してのみ修正することになる.

以上, 述べたように重心基準㣚体化処理法とは平均值 の原理に基づき観測値から䛊差が確率的に最も少なくな る点, すなわち重心を求め, 以後この点を基準として解 析をすすめることで, 解析過程での證差の増大を可及的 に防止することを目的としたデータ処理法である.

\section{3. 観測精度を剛体条件より推定する方法}

写真法で得られるデータの要素数はその下顎位を一義 的に定めるために最小限必要な要素数より多く得られる ことが多い.このて長データがある場合には実験全体の 観測精度について統計学的に判定できるとともに，個々 のデータについてもその精度をある程度まで推定するこ とができる. 例えば, 2 点 2 次元の場合観測データの要 素数は 4, 必要要素数は 3, 几長要素数は 1 で㣚体条件 による束縳要素は 1 である.

観測データに誤差が含まれている場合の誤差の符号に ついて考察してみる. そこでは用体条件を满たさないよ うな組み合わせの場合と, 逆に見かけ上用体条件を满た す方向の組み合わせとが等確率で起こる.したがって， 1 要素の刚体条件を満たすからといって，ただちにその データが正しいと断定することはできないが，逆に㴊体 条件を満たさない場合は明らかに袈差を含んでいるとい
える. 見かけ上条件を満たす方向と, 乱す方向は等確率 で起こるので全体のデータを統計学的に評価することは できる．見かけ上誤差が大きくなる場合は誤差の符号は 正負等確率で起こるはずである. もし等確率でない場合 は何らかの原因による系統誤差が含まれている可能性が 大で, 解析によってとり除ける可能性がある. また，観 測データの各要素に関して同じ大きさの俱差が存在して も，㴊体条件を乱しやすい感度の高い方向の要素とこれ に垂直な感度の低い方向の要素とが存在する.

3 点 3 次元の場合, 観測データの要素数は 9, 必要要素 数は 6 ，几長要素数は 3 で剛体条件による束縛要素数は 各標点間の長さについて 3，その各辺のなす角について 3である. いま各辺の長さだけをチェックの対象として 各辺について見かけ上誤差が打ち消される場合と桩大さ れる場合の確率をおのおの $1 / 2$ とすると, 誤差が存在す るのに 3 辺そろって偶然に剛体条件が満たされる確率は $(1 / 2)^{3}=1 / 8$ 以下である. 上下影ともに 3 点 3 次元測定し ている場合に上下滪の各 3 辺, 計 6 辺のすへてについて の剛体条件の成立が偶然に起こる確率は $1 / 8 \times 1 / 8=1 / 64$ より高くはない.したがって，このような場合にはその データを正しいと判定しても誤りを犯す危険は小さい.

さらに, 3 点 3 次元測定より標点を増やして 4 点 3 次 元6)とした場合に得られる観測データ要素数は 12 , 必要 要素数は 6 , 几長要素数は 6 となり, 標点間距離につい ての㓮体条件による束縛条件は 6 となる.

栗山12)の用いた絶対写真計測法で, 上顎は 9 標点, 下 影は 3 標点でチェックした束縛要素は 12 であった.こ れがすべて満たされている場合に，偶然そうなる確率沬 $(1 / 2)^{12}=1 / 4096$ より低く, 正しいと判定しても埕りを犯 す危険性はほとんどない.この方法で上顎 9 標点につい て得られる観測データ要素数 27 , 必要要素数 6 , 几長要 素数 21 であり, 各標点閒の距離に関する束䌗要素数は 36 である. 実際にはこのうちの 9 要素についてチェッ クを行った.

\section{IV. 絶対写真計測法について}

本計測法については，既に概略は報告してあるが122， 以下の 3 点を目標として開発したものである.

(1) 従来の測定法は咬頭嵌合位で重ねあわせること で, 各下㴿運動経路を比較するという咬頭嵌合位に対す る相対位置の測定法であったのに対し，咬頭嵌合位がな くとも測定比較のできる絶対測定が可能な方法とする.

（2）上顎に対する純粋な下顎運動をとり出し，データ 
$98-682$

は任意の点の運動を容易に計算できるような標準形に直 して整理する.

(3) 測定精度は石原 ${ }^{14)}$ 以来下䇗運動測定の基準となっ ている $0.1 \mathrm{~mm}$ を一応の目標とする.

などを念頭に置いて従来の測定器 ${ }^{11)}$ ，測定方法の改良 を行ったので，以下データ処理の順に従い，処理方法と 改良点について述へる.

\section{1. 下顎運動測定装置の構成}

下顎運動測定装置は，(1)撮影用カメラ（マミヤ・ユニ バーサル・プレス：レンズの焦点距離 $\mathrm{f}=100 \mathrm{~mm}, \mathrm{~F}$

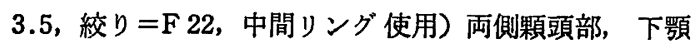
切歯点部各 1 台, 計 3 台, (2)ポラロイドフィルム Type 107 and 667, (3)タイマー ${ }^{15)}$ と新たに製作した電力増幅 回路からなる標点点隇装置, なお標点ランプの点灯特性 ならびに寿命の改善を図るため予熱回路をもうけた，(4) 頭部固定装置 ${ }^{11)}$ ，(5)標点, 濱井電球社製 No.-0041 を フィルム位置基準用に各カメラ前に 4 個, 計 12 個, 頭 部動摇測定用に上影 Face-bow の各カメラ前に 3 個, 計 9 個そして下頡運動測定用に下顎 Face-bow の両側顆頭 部, 下顎切歯部に各 1 個, 計 3 個, 標点総数 24 個, (6) 座標誢取装置 ${ }^{11}$ ，等より構成され，データ処理は東京大 学大型計算機センターにて行った.

\section{2. ポラロイドフィルム上の標点の座標值の求め方に} วいて

カメラの前に固定した標点を㯰き，この標点を何枚か のフィルムに撮影すると標点は毎回各フィルムの同し位 㯰に撮影されるわけではない.これはフィルムがカメラ 内で撮影時に同じ位置をとらないために起こる現象であ る.このためにデータはフィルム上で平行移動, 回転, 扡大, 縮小されて撮影されることになる. 基準位とすべ き咬頭崁合位が撮影されていないフィルム間のデータを 比較するためにはこの影響をとり除かなければならな い. そこで, 各カメラの前の 4 隅に 4 個の標点を設置し て, フィルム上のそれらの標点の座標値が予備実験で定 めた標準值に戻るように各フィルム毎に回帰式の係数を 求め, そのフィルム上の全データをその倸数を使った回 㷌式で基準化処理した. すなわち，フィルム上には図 5 に示ように 4 隅に基準標点 $P\left(x_{p}, y_{p}\right), Q\left(x_{q}, y_{q}\right)$, $R\left(x_{r}, y_{r}\right), S\left(x_{s}, y_{s}\right)$ の 4 点が最影されている. 予備 実験で求めた 基準座標值を $\mathrm{P}\left(\mathrm{X}_{\mathrm{P}}, \mathrm{Y}_{\mathrm{P}}\right), \mathrm{Q}\left(\mathrm{X}_{\mathbf{Q}}, \mathrm{Y}_{\mathbf{Q}}\right)$, $R\left(X_{R}, Y_{R}\right), S\left(X_{S}, Y_{S}\right)$ とすれば, $x, y$ それぞれにつ Wて

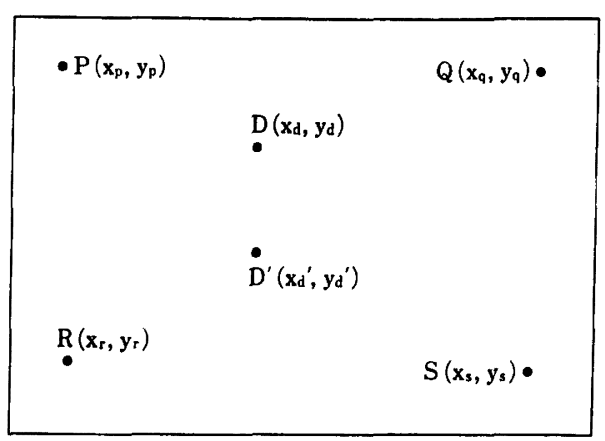

図 5 撮影された標点

フィルム位置基準化のための 4 郦の標点 $\mathrm{P}, \mathrm{Q}, \mathrm{R}, \mathrm{S}$ と 2 方向からみた観測標点 $\mathrm{D}, \mathrm{D}^{\prime}$ が撮影される.

$$
\begin{aligned}
& \left\{\begin{array}{l}
X_{P}=A_{1}+A_{2} x_{p}+A_{3} y_{p}+A_{4} x_{p} y_{p} \\
X_{Q}=A_{1}+A_{2} x_{q}+A_{3} y_{q}+A_{4} x_{q} y_{Q} \\
X_{R}=A_{1}+A_{2} x_{r}+A_{3} y_{r}+A_{4} x_{r} y_{r} \\
X_{S}=A_{1}+A_{2} x_{0}+A_{3} y_{9}+A_{4} x_{0} y_{s}
\end{array}\right. \\
& \left\{\begin{array}{l}
Y_{P}=B_{1}+B_{2} x_{p}+B_{3} y_{p}+B_{4} x_{p} y_{p} \\
Y_{Q}=B_{1}+B_{2} x_{q}+B_{3} y_{q}+B_{4} x_{q} y_{q} \\
Y_{R}=B_{1}+B_{2} x_{r}+B_{3} y_{r}+B_{4} x_{r} y_{r} \\
Y_{S}=B_{1}+B_{2} x_{s}+B_{3} y_{\mathrm{q}}+B_{4} x_{8} y_{q}
\end{array}\right.
\end{aligned}
$$

となる.ここで(1)式および(2)式が成立するように $A_{1} \sim$ $\mathrm{A}_{4}$ および $\mathrm{B}_{1} \sim \mathrm{B}_{4}$ について連立方程式を解く．ついで， フィルム上のデータ $\mathrm{D}\left(\mathrm{x}_{\mathrm{d}}, \mathrm{y}_{\mathrm{d}}\right)$ について次式により基 淮化データ $D\left(X_{D}, Y_{D}\right)$ を得る.

$$
\begin{aligned}
& X_{D}=A_{1}+A_{2} x_{d}+A_{3} y_{d}+A_{4} x_{d} y_{d} \\
& Y_{D}=B_{1}+B_{2} x_{d}+B_{3} y_{d}+B_{4} x_{d} y_{d}
\end{aligned}
$$

以上の処理を鏡を通した像 $\mathrm{D}^{\prime}\left(\mathrm{x}_{\mathrm{d}}, \mathrm{y}_{\mathrm{d}}\right)$ を始め, 撮影 されているすべての標点について行う.また，この処理 は各カメラ, 各フィルム毎にすべて行う.これにより処 理前の標準偏差 $\mathrm{x}$ 方向 $0.294 \mathrm{~mm}$ (図 6), $\mathrm{y}$ 方向 0.275 $\mathrm{mm}$ (図 7), 拡大, 縮小率 $0.295 \%$ (図 8), 回転 0.061 度（図 9) とバラッキのあった值を，各フィルム間の重 ね合わせが可能なように基準化データとすることができ た.

この処理により各フィルムが警曲せず平面性を保って いるかぎりはフィルムの位置ずれによる影響を除くこと ができるとともに, 座標読取装置の水銀電池の電圧変動 による影響等も取り除くことができる.すなわち，同し 空間位にある標点はフィルム上で常に対応する $2 つ の 2$ 次元座標値として測定されることになる.

\section{3. フィルム上のテータから空間座標値の求め方} 空間における各標点の位㯰はフィルム上の 2 次元座標 

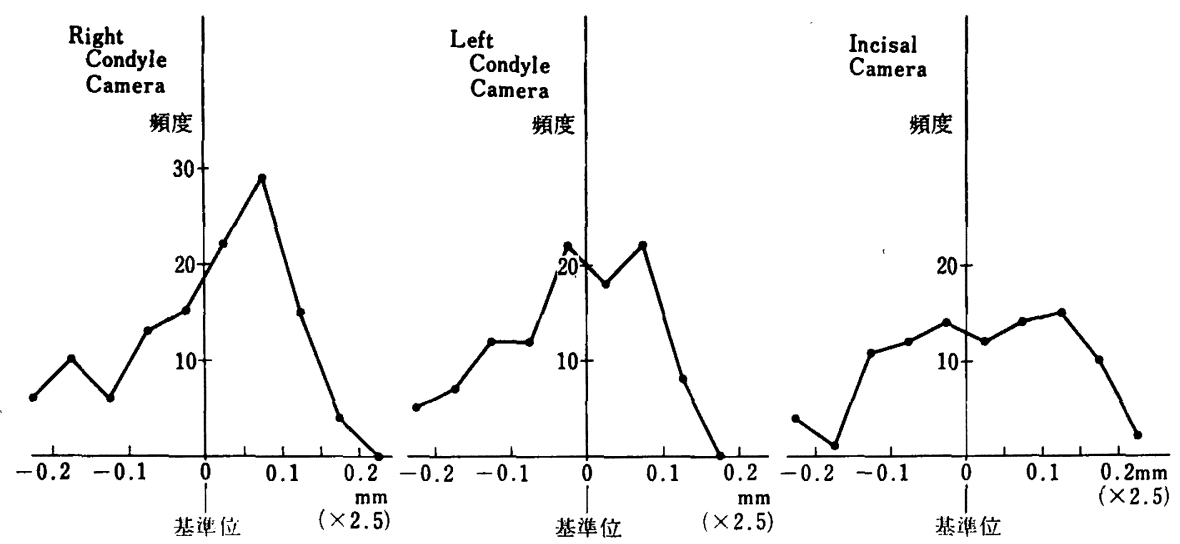

図 6 ポラロイドフィルムの各カメラ内での $\times$ 方向のずれ（栗山）

図のスケールはポラロイドフィルムずれの大きさであり観測標点の運動は $1 / 4$ に

縮小されて撮影されているので観測データに及ぼす影㹕は 2.5 倍となる.
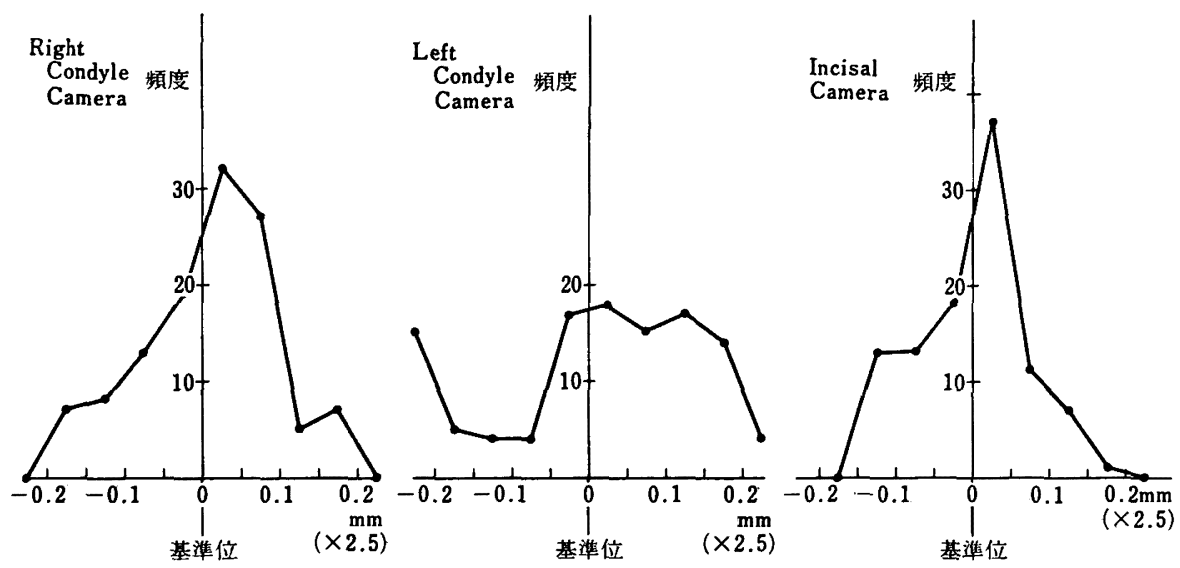

図 7 ポラロイドフィルムの各カメラ内でのy方向のずれ（栗山）

横軸のスケールの意味は図 6 と同じ.
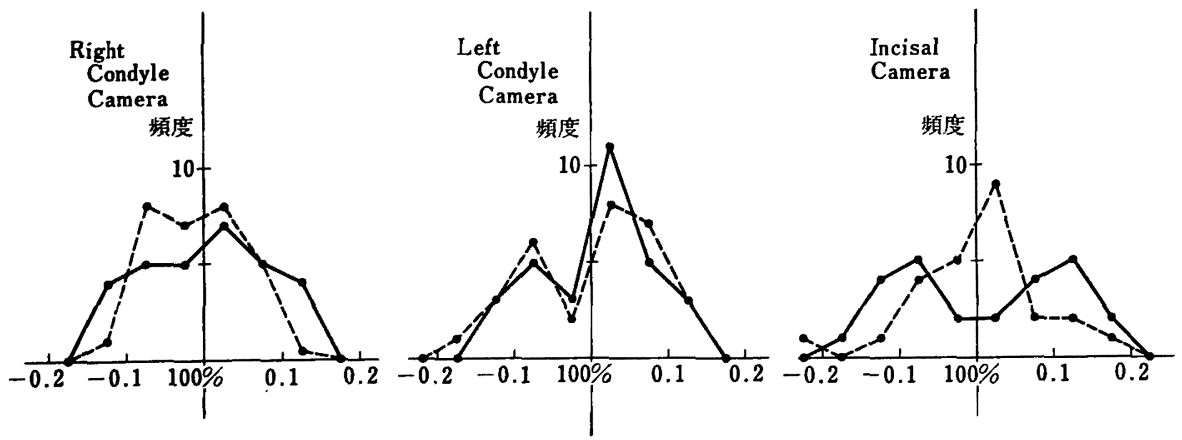

图 8 ポラロイドフィルムに摄影される扡大, 縮小率 基準位標点間距離を横軸 $100 \%$ にとってある. 実線と破線は 4 阴の各々の対角線を示す. 


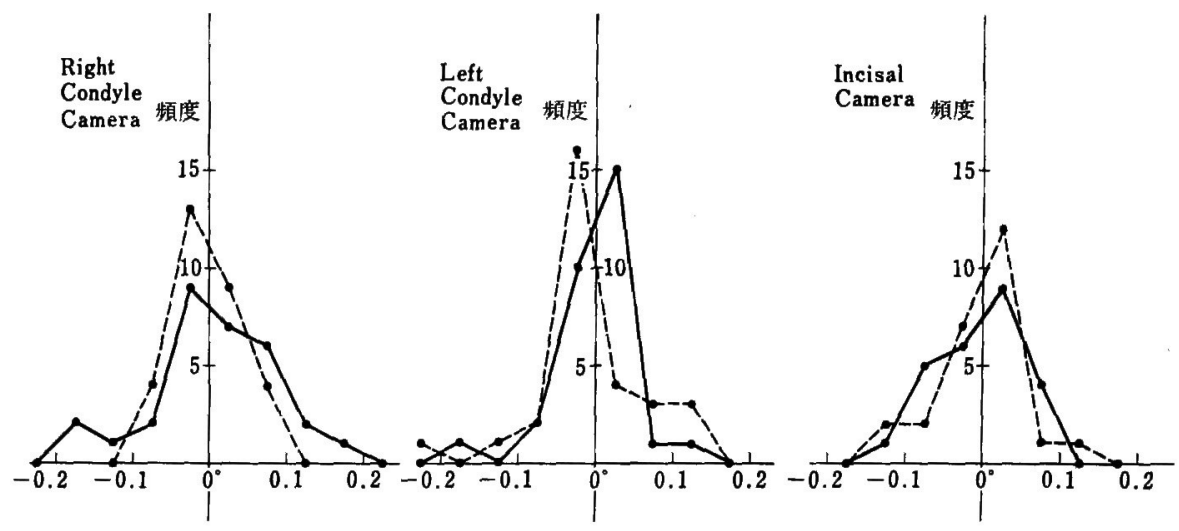

図 9 ポラロイドフィルムの各カメラ内での回転 横軸は基準位のフィルムを 0 度として角度で表示. 実線と破線は图 8 と同じ.

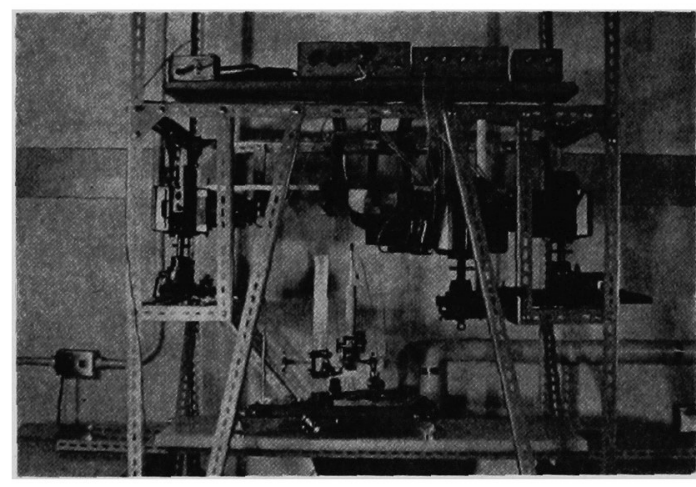

図 10 絶対写真計測のための較正実験

值として得られるが, この值は光学的な歪を受けてい る. また，各カメラ間には光軸のずれ，位置設定誤差等 が存在する.これらの誤差在修正し，各標点に統一した 3 次元座標値を求めるために以下の較正を行った． ず，3 次元読取顕微鏡)を大地に固定して，鏡筒部に実 験に使用するものと同じ標点用ランプを取り付けた（図 10). このランプを各カメラの前で下額運動の範囲 を含 むように 3 次元的に動かし，それぞれの位置で写真撮影 を行った. 顆頭部では 150 点を 30 枚のフィルムに撮影 し, 切歯部では 150 点について 25 枚の撮影を行った.

読取䫓微鏡のある位置 ( $\left.\mathrm{x}_{\mathrm{E}_{1}}, \mathrm{y}_{\mathrm{E}_{1}}, \mathrm{z}_{\mathrm{E}_{1}}\right)$ に対し, 顆頭 部では直接撮影の矢状面投影に近いデータ $\left(x_{d}, z_{d}\right)$ と 鏡を通した水平面投影に近いデータ $\left(x_{d}, y_{d}\right)$ が 得 ら れ，切歯部では鏡で 2 度反射した前頭面投影に近いデー 夕 $\left(\mathrm{y}_{\mathrm{d}}, \mathrm{z}_{\mathrm{d}}\right)$ と同しく矢状面投影に近いデータ $\left(\mathrm{x}_{\mathrm{d}}, z_{\mathrm{d}^{\prime}}\right)$ が得られる. 大地系空閒座標 $\left(X_{E}, Y_{E}, Z_{B}\right)$ のそれぞれ の要素について写真より得られた観測データについて各
8 項からなる次式のような回帰式を考えてみた.

$$
\begin{aligned}
& \mathrm{x}_{\mathrm{E}_{1}}=\mathrm{A}_{0}+\mathrm{A}_{1} \mathrm{x}_{\mathrm{d}}+\mathrm{A}_{2} \mathrm{y}_{d}+\mathrm{A}_{3} \mathrm{z}_{\mathrm{d}}+\mathrm{A}_{4} \mathrm{x}_{\mathrm{d}} \mathrm{y}_{d}+\mathrm{A}_{5} \mathrm{y}_{\mathrm{d}} \mathrm{z}_{\mathrm{d}} \\
& +A_{6} z_{d} x_{d}+A_{7} x_{d} y_{d} z_{d} \\
& y_{E_{i}}=B_{0}+B_{1} x_{d}+B_{2} y_{d}+B_{3} z_{d}+B_{4} x_{d} y_{d}+B_{5} y_{d} z_{d} \\
& +\mathrm{B}_{6} \mathrm{z}_{\mathrm{d}} \mathrm{x}_{\mathrm{d}}+\mathrm{B}_{7} \mathrm{x}_{\mathrm{d}} \mathrm{y}_{\mathrm{d}} \mathrm{z}_{\mathrm{d}} \\
& z_{E_{i}}=C_{0}+C_{1} x_{d}+C_{2} y_{d}+C_{3} z_{d}+C_{4} x_{d} y_{d}+C_{5} y_{d} z_{d} \\
& +\mathrm{C}_{6} \mathbf{z}_{\mathrm{d}} \mathrm{x}_{\mathrm{d}}+\mathrm{C}_{7} \mathrm{x}_{\mathrm{d}} \mathrm{y}_{\mathrm{d}} \mathbf{z}_{\mathrm{d}} \cdots \cdots \cdots \cdots \cdots \cdots \cdots \cdots \cdots \cdots \cdots \cdots(7) \\
& \text { * }\left(A_{i}, B_{i}, C_{i}, i=0 \sim 7\right)
\end{aligned}
$$

(5)，(6)，(7)式それぞれに決定すべき係数は 8 項(*) ある が，較正実験より与えられる式は 150 個（i=1～150）あ るので充分解ける。 そこで，最小 2 乗法にて係数を求 め，(5)，(6)，(7)式の右辺に代入すると，それぞれのデー タについて空間座標 $\left(\mathrm{X}_{1}, \mathrm{Y}_{1}, \mathrm{Z}_{1}\right)$ が求まる.このとき 空間座標決定誤差

$$
\begin{aligned}
& \mathrm{ex}_{i}=X_{i}-X_{E_{i}} \\
& \text { ex }_{1}=Y_{1}-Y_{E_{i}} \\
& e_{z_{i}}=Z_{i}-Z_{B_{i}}
\end{aligned}
$$

をそれぞれのカメラについて求め，その頻度分布を示し たのが，図11である.なお，e $\mathrm{e}_{\mathrm{x}_{1}}, \mathrm{e}_{\mathrm{x}_{1}}$ ， $\mathrm{ez}_{z_{1}}$ のあまりに 大きいものは人為的なミスと認定してデータから取り除 き, 再度倸数を求め直した. これにはソフトウェアで自 動的に判定する方法 ${ }^{16)}$ あるが，今回は実験者がそのつ どすべてのデータに目を通して判定する方法をとった. 同時にさらに係数の多い(11)式の形式

$$
\begin{aligned}
X_{E_{1}} & =A_{0}+A_{1} x_{1}+A_{2} y_{1}+A_{3} z_{1}+A_{4} x_{1} y_{1}+A_{5} y_{1} z_{1} \\
& +A_{6} z_{1} x_{1}+A_{7} x_{1}^{2}+A_{8} y_{1}^{2}+A_{9} z_{1}^{2}+A_{10} x_{1} y_{1} z_{i} \\
& +A_{11} x_{1}^{2} y_{1}+A_{12} y_{1}^{2} z_{1}+A_{13} z_{1}^{2} x_{1}+A_{14} x_{1} y_{1}^{2} \\
& +A_{16} y_{1} z_{1}^{2}+A_{16} z_{1} x_{1}^{2}+A_{17} x_{1}^{2} y_{1}^{2}+A_{18} y_{1}^{2} z_{1}^{2} \\
& +A_{19} z_{1}^{2} x_{1}^{2}+A_{20} x_{1}^{2} y_{1} z_{1}+A_{21} y_{1}^{2} z_{1} x_{1}+A_{22} z_{1}^{2} x_{1} y_{i}
\end{aligned}
$$



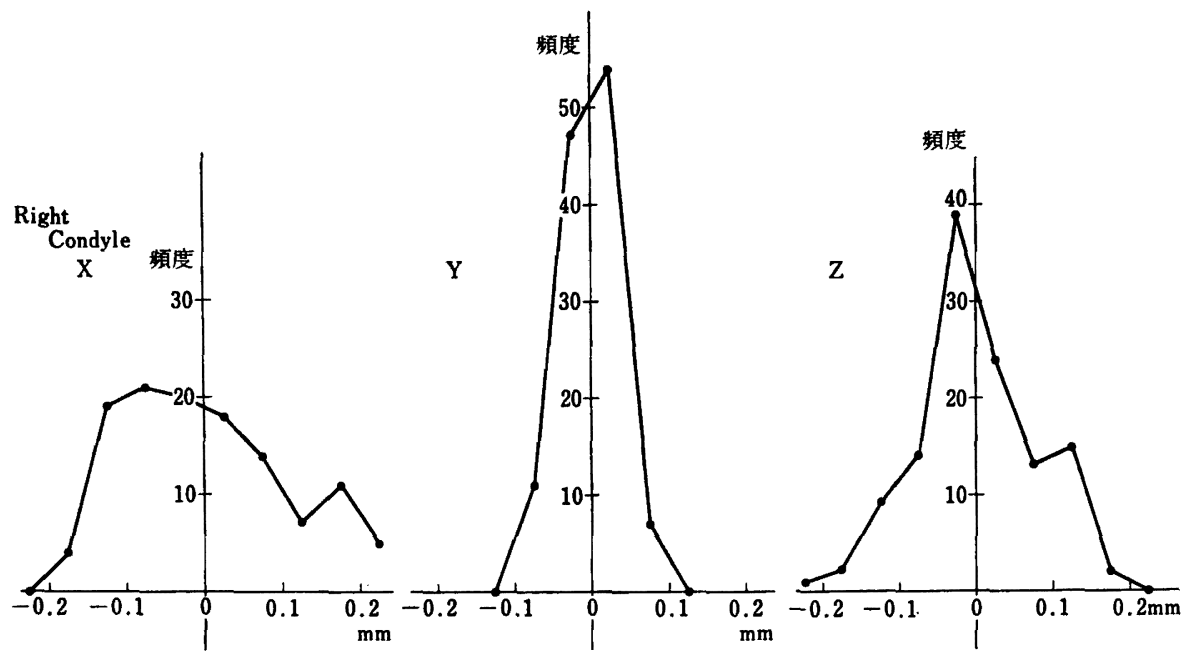

(a)
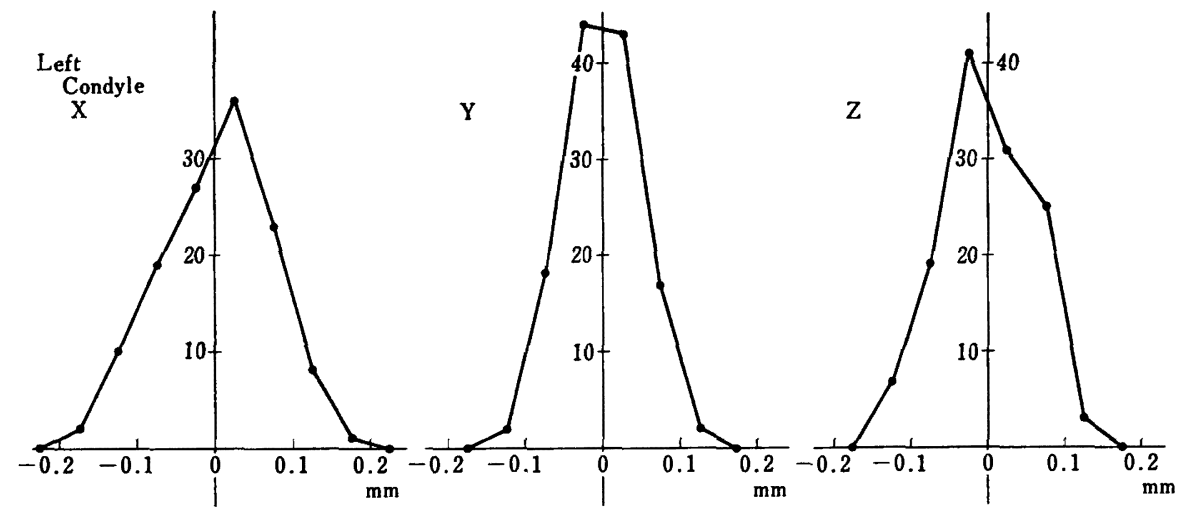

(b)

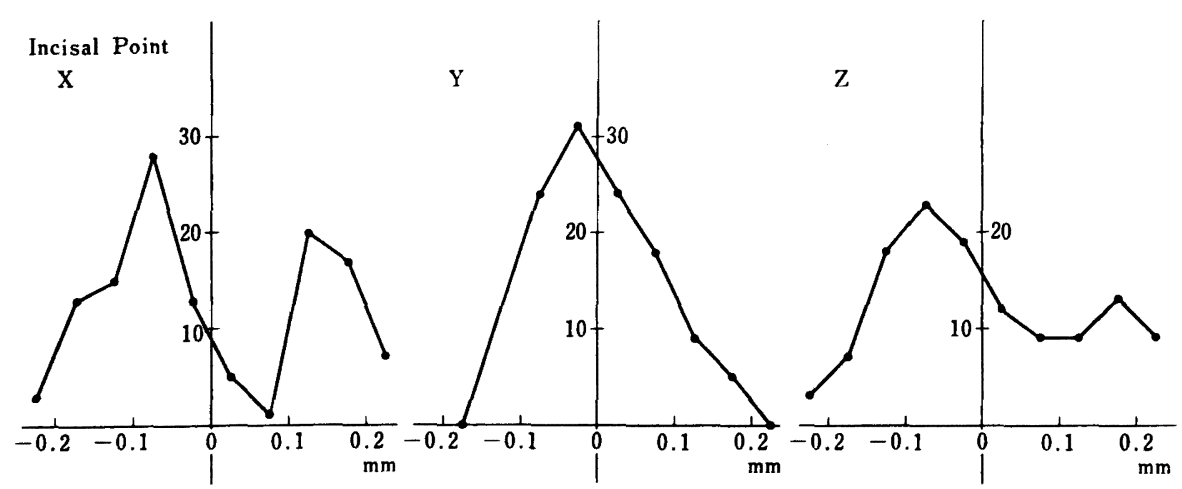

(c)

因 11 䎦対写真計浿較正実験における空間座標決定碏差頻度分布曲線 


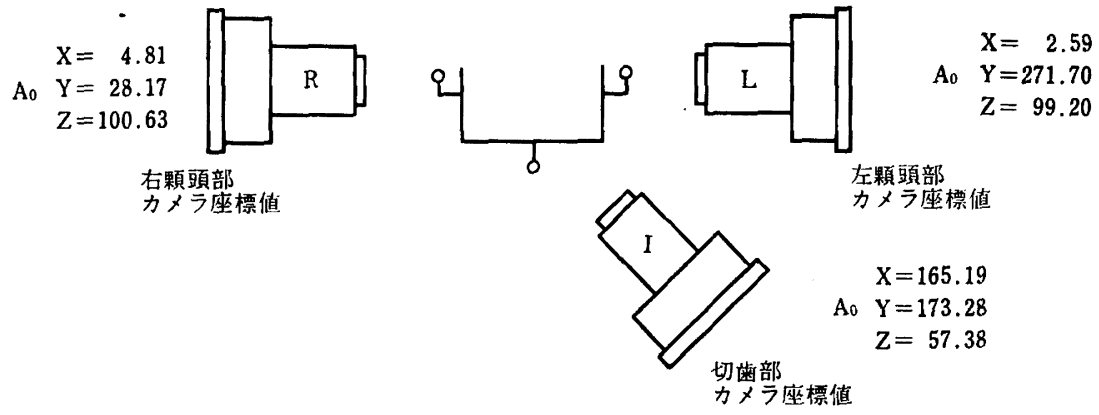

\begin{tabular}{|c|c|c|c|c|c|c|c|c|c|}
\hline & & $\mathrm{R}$ & & & I & & & $\mathrm{L}$ & \\
\hline , B,C & $\mathrm{X}$ & $Y$ & $Z$ & $\mathrm{X}$ & $Y$ & $Z$ & $\mathrm{X}$ & $Y$ & $Z$ \\
\hline$i=0$ & 4.81 & 28.17 & 100.63 & 165.19 & 173.28 & 57.38 & 2.59 & 271.70 & 99.20 \\
\hline 1 & 2.38 & $2.82 \mathrm{E}-2$ & $-4.92_{E}-2$ & -3.12 & $3.31 \mathrm{E}-2$ & $3.70 \varepsilon-2$ & -2.44 & $-2.52_{\mathrm{E}}-2$ & $-6.00 E-3$ \\
\hline 2 & $-3.33 E-2$ & 2.42 & $2.60_{E}-2$ & $-5.93_{E}-2$ & 3.08 & $-1.06 \varepsilon-2$ & $4.85 E-2$ & -2.44 & $5.27 \mathrm{E}-2$ \\
\hline 3 & $-4.19_{E}-2$ & $-1.09_{E-1}$ & -2.39 & $1.72 \mathrm{E}-2$ & $-3.22 \mathrm{E}-2$ & -3.07 & $1.76_{\mathrm{E}}-2$ & $6.83 E-2$ & -2.43 \\
\hline 4 & $2.88_{E}-2$ & 7. $69_{E}-4$ & $-3.05 E^{-4}$ & $5.70 \mathrm{E}-2$ & $5.44_{E}-2$ & $-4.88 E-4$ & $-3.01_{\mathrm{E}}-2$ & $-3.82 \mathrm{E}-4$ & $-5.58 \mathrm{E}-5$ \\
\hline 5 & $-4.64 \mathrm{E}-4$ & $2.70 E-2$ & $-2.92 \mathrm{E}-2$ & $-4.33 \mathrm{E}-4$ & $3.21_{E}-4$ & $-4.93 E-4$ & $3.90 E-4$ & $-2.83_{E}-2$ & 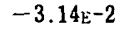 \\
\hline 6 & $-1.46 \mathrm{E}-3$ & $-2.47_{E}-4$ & $-5.06 \mathrm{E}^{-4}$ & $3.60 \mathrm{E}-4$ & $2.51 \mathrm{E}-4$ & $-4.57 \mathrm{E}-2$ & $1.20 \mathrm{E}-3$ & $-9.05 E-5$ & $-4.92 E-4$ \\
\hline 7 & $3.00 \mathrm{E}-4$ & $5.16 E-5$ & 4. $24_{\mathrm{E}}-5$ & $1.15_{E}-4$ & $1.07_{E-4}$ & $7.97 E^{-4}$ & $-2.61_{E}-4$ & $-3.77_{E}-5$ & $3.40 \mathrm{E}-5$ \\
\hline
\end{tabular}

$+A_{23} x_{1}^{2} y_{1}^{2} z_{1}+A_{24} y_{1}^{2} z_{1}^{2} x_{1}+A_{25} z_{1}^{2} x_{1}^{2} y_{1}$

$+\mathrm{A}_{26} \mathrm{x}_{1}^{2} \mathrm{y}_{1}^{2} \mathrm{z}_{1}^{2}$ (11)

（各カメラについて， $\mathrm{i}=1 \sim 150)$

についてもすべてのカメラの各要素すべてのデータにつ いて検討したが，今回は(5)，(6)，(7)式の形式を探用した (図 11).このため得られた係数は各カメラ, 各要素 ( $x$ $\mathrm{y}, z)$ 毎に 8 個，合計 72 個である. 保数の一覧表を表 2 に示す. 表の值より各カメラの相互位置は右顆頭部力 メラ $(\mathrm{X}=4.81, \mathrm{Y}=28.17, \mathrm{Z}=100.63)$, 左顆頭部カメ ラ $(\mathrm{X}=2.59, \mathrm{Y}=271.70, \mathrm{Z}=99.20)$, 切歯部カメラ $(\mathrm{X}=165.19, \mathrm{Y}=173.28, \mathrm{Z}=57.38) \mathrm{mm}$ となることがわ

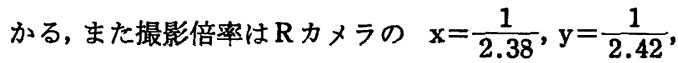
$z=-\frac{1}{2.39}, \quad$ I カメラの $x=-\frac{1}{3.12}, y=\frac{1}{3.08}, z=-$ $\frac{1}{3.07}$, Lカメラの $\mathrm{x}=-\frac{1}{2.44}, \mathrm{y}=-\frac{1}{2.44}, z=-\frac{1}{2.43}$ であることを読み取ることができる.この処理により写 真撮影されたデータは正しく空間座標, すなわち読取顕 微鏡による大地系の座標(I)に変換される. 今回探用した (5)〜(7)式および検討した(1)式の形式ともにデータの $x_{d}$, や Z $\mathrm{d}^{\prime}$ を捨てている. 前章で検討した重心基準化の考え 方に従えばこれらのデータは捨てるべきではなく，点D $\left(X_{E}, Y_{E}, Z_{E}\right)$ に対し, 写真上でデータ $\left(d_{1}, d_{2}\right),\left(d_{3}\right.$, $\mathrm{d}_{4}$ ) が得られたとき,

$D_{X B}=k_{1}+k_{2} d_{1}+k_{3} d_{2}+k_{4} d_{3}+k_{5} d_{4}+k_{6} d_{1} d_{2}+k_{7} d_{2} d_{3}$ $+k_{8} d_{3} d_{4}+k_{9} d_{4} d_{1}+k_{10} d_{1} d_{2} d_{3}+k_{11} d_{2} d_{3} d_{4}+k_{12} d_{3} d_{4} d_{1}$

$+k_{13} d_{4} d_{1} d_{2}+k_{14} d_{1} d_{2} d_{3} d_{4}$ (12)

( $D_{\mathrm{YE}}, \mathrm{D}_{\mathrm{Z}}$ Кついても同様)

(12)式のような形式を検討すべきであった.

\section{4. 純粋な下䫓運動の求め方}

咬頭嵌合位における下領右側顆頭部の標点を原点と し，全運動軸を $\mathrm{y}$ 軸これに垂直でカンペル平面と平行な 軸を $\mathrm{x}$ 軸, 両者に垂直な軸を $\mathrm{z}$ 軸として, 先の大地系の 座標 (I) を各被験者毎の座標系 (II) へ変換しこれを基準 座標系とする. この咬頭嵌合位において上額に設定した 座標系(III) と下頭に設定した座標系(IV)は原点および各 軸ともその被験者の基準座標系に一致させる.

各フィルム毎, 各運動每に下顎座標系(IV)から，その ときの上頡座標系(III)の被験者基準座標系に対する運動 を消去すれば, 各被験者の基準座標系に対する純粋な下 䫟運動 $(\mathrm{V})$ が求まることになる. いいかえれば上顎の座 標系(III)が運動するたびにその值を求め,これが被験者 の基準座標系(II)に一致するように，下䫟運動データの 座標変換を行い, 上䫑に対する純粋な下顎運動 $(\mathrm{V})$ を求 めるのである. このとき各座標系の運動を

$$
\left[\begin{array}{cccc}
l_{1} & l_{2} & l_{3} & x_{0} \\
m_{1} & m_{2} & m_{3} & y_{0} \\
n_{1} & n_{2} & n_{3} & z_{0}
\end{array}\right]
$$

(13)式の形で表現する. 互に独立した 6 個のパラメータが 
あれば剛体の空間における位置は一義的に定まるが，種 々の取り扱いに際して(13)式の形式が便利なのでこれを探 用した. (13)式は方向余弦に関して 9 個，原点の移動に関 して 3 個の要素を持っている. 各要素の値は被験者の基 準座標系の各樽点の座標値をもとにして日立製作所提供 の 1 倍精度最小 2 乗法 (LESQ 1) ${ }^{17}$ ) 1 倍精度掃出し法 (LINS 1) ${ }^{17}$ のサブルーチンを利用して計算により求め た. 各標点の座標值の数值の大きさは, 例えば右側顆頭 の y 座標値はほぼ 0.0 であるのに左側顆頭部のそれは 300.0 程度の大きな数值となり, その間に 2 3 桁位の ひらきがある. このためそのままで計算すると LINS 1 より行列が特異であるとの警告文が計算の都度出力され る. そこで，原点を $(-100.0,-100.0,-100.0)$ に 移した計算機内部座標系に変換して, 各数值の見掛けの 析数をほほ等しくしてから計算した. これにより警告文 は出なくなったが，見掛けの相対誤差がほぼ等しくなっ ただけで絶対誤差が小さくなったわけではない、ソフト ウェア的に警告文が出ないようにすることは容易だが， 計算機の各チェック機能を充分に活用するということか ら上記の方法をとった. したがって, 計算機内部での以 後の計算はすべて計算機内部座標系により行い，入出力 部に変換ルーチンを設けることで被験者の基準座標系と の対応を図った，実際の計算手順は以下のように行っ た.

一直線上にない3 点のそれぞれから独立の 6 要素を選 び出せば㓮体の空間に㧍ける状態を一義的に決定するこ とはできる. しかし，今回は重心基準剛体化処理法の考 え方を一部とり入れて, 左右顆頭部 (LR), 切歯部 (I) の 3 標点が作る三角形 (RLI) の平面上に各標点の重み 係数 1.0 で重心(G) を求め, さらにこの平面に重心を通 る垂線をたてて平面からの距離 $100 \mathrm{~mm}$ のところに点 $\mathrm{P}$ を求める. 直交座標系 $\mathrm{I}(\mathrm{x}, \mathrm{y}, \mathrm{z})$ から回転および平行 移動した直交座褾系 II $(\mathrm{X}, \mathrm{Y}, \mathrm{Z})$ への変換式は

$$
\left.\begin{array}{l}
x=1_{1} X+1_{2} Y+1_{3} Z+x_{0} \\
y=m_{1} X+m_{2} Y+m_{3} Z+y_{0} \\
z=n_{1} X+n_{2} Y+n_{3} Z+z_{0}
\end{array}\right\} \cdots \cdots \cdots \cdots \cdots \cdots(14)
$$

で与えられる.つまり式偣の各行の未知数 4 個に対して $(R, L, I, G, P)$ の 5 点から各 5 個の方程式が得られ, これを各行ごとにそれぞれ最小 2 乘法で解くことにより (13)式の 12 要素がすべて求まる.

運動の最初のフィルムには上顎の標点が各カメラ毎に 3 点, 計 9 点ある. それらフィルムについてそれぞれの カメラ部から 1 点ずつ標点を選び出し， 3 個の平面につ いて Gと Pを求める. ここで(13)式の各行 4 個の要素を求
めるために 15 個の式が成立し，それぞれを最小 2 乗法 で解いた.

この方法は剖体化処理としては非常にゆるやかなもの であり，(14)式にその点の座標值を代入して各標点の位置 を再度計算すると生データに近いものが得られる. 用体 条件のくずれは各方向余弦に吸収された形であるので, 各軸の直交条件等は完全には満たされていない，上影の 座標系をこのように処理した後，下頡の標点のデータ修 正を行う場合, 各カメラ毎に起因する系統誤差が存在す る場合には，これは有効な方法である.しかし，シャッ ターのセット, フィルムの着脱等でカメラの位置が動か ないように固定を強化するなどの対策を施してあるの で，このような処理法がよいのか，完全に用体化処理を する方がよいのかは第 6 項で検討する．、ずれにせよ原 データが正しく得られていれば，どちらの処理方法によ っても正しい結果が得られるので，上䅡座標系の動きを

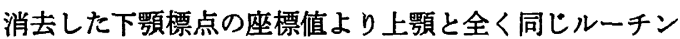
を使用して純粋な下顎運動を求めた.

\section{5. その他の誤差要因}

(1) 温度, 湿度変化の影響

測定器 (図 10) のうち測定に直接関与する頭部固定装 置, 写真撮影装置の部分の大きさは約 $30 \mathrm{~cm} \times 30 \mathrm{~cm}$ $\times 30 \mathrm{~cm}$ である. これらは一部アルミ材が使用されてい るが，ほとんどは鉄材が使用されている．したがって， 装置のこの部分の温度変化による膨縮 は $30 \mathrm{~cm} \times 20 \times$ $10^{-6} /{ }^{\circ} \mathrm{C}=6 \mu \mathrm{m} /{ }^{\circ} \mathrm{C}$ 程度と考えられる.この值は $10^{\circ} \mathrm{C}$ の 温度変化で $60 \mu \mathrm{m}$ 程度であるので，特に補正は行わな かった. また，ポラロイドフィルムの膨縮，座標読取器 の温度による変化等の影響が考えられるが，これらの膨 縮が一様に生ずるかぎり，先に述べたカメラ前の 4 基準 標点の座標值を常に標準值に戻す操作で補正できる．ま た，今回はポラロイドフィルムにコーティング処理が不 要な Type 667 を採用したので, フィルムの膨縮による 影響は相当に小さくなり，実測值にみられるようにほと んど問題はなくなった（図 11).

(2) 計算誤差

各種演算は，特に誤差の増大が予想される特別な場合 を除いては 32 bit 単精度浮動小数点で行った.これは 10 進で仮数部 7 析余の精度であり, 累積誤差は最大下 2 析程度と考えられる ${ }^{17)}$ 。この研究では $30 \mathrm{~cm}$ 程度の範 囲を研究対象とするため計算誤差が $30 \mathrm{~cm} \times 10^{-5}=3 \mu \mathrm{m}$ を越えることはないと考えられる。 
（3）生体に座標軸を設定する際の誤差

先に述べたような方法で各被験者ごとに基準座標系を 設定した. Y 軸は運動論的に決定された全運動軸を採用 しているが，X軸はカンペル平面という形態学的な基準 に平行に定めている.このことが同一被験者の繰り返し 実験および被験者間のデータを比較するときにどのよう な意味を持っているのかは今後の研究課題としたい.

\section{6. 小括ならびに考案}

この研究での測定精度は 1 標点の空間座標測定に関し ては，すべての標点のすべての方向に対し図 11 に示し たように R, L, I の標準偏差の平均值は $0.094 \mathrm{~mm}$ で

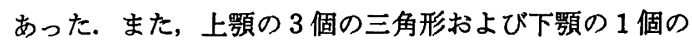
三角形の各辺の長さの基準長に対する差分を各データ毎
に出力して測定精度の基準とした（図 12）. 図 12 に示す ように上䅡に設圆した標点の翤体条件のくずれからみた 精度は標点間距離の差の標準偏差の平均 $0.109 \mathrm{~mm}$, こ れの相対誤差は各辺約 $210 \mathrm{~mm}$ であるので，0.05\%とな る. 下顥に設置した標点の㴊体条件は上頡の動きを修正 する前は標準偏差 $0.072 \mathrm{~mm}$, 上䪽の動きの修正後は $0.250 \mathrm{~mm}$ であった.したがって,最終的に得られた標準 形のデータにおいて直交性の乱れも同じ程度となった。 これらの值は各測定値毎にプリントアウトしたので，個 々のデータの評価が可能である.

上顎の動きの修正の前後において下䫑標点の用体条件 の乱れが拡大したことについて, 少し 補足説明してみ る. 誤差は演算操作において伝搬するが，加減算処理の 場合それは

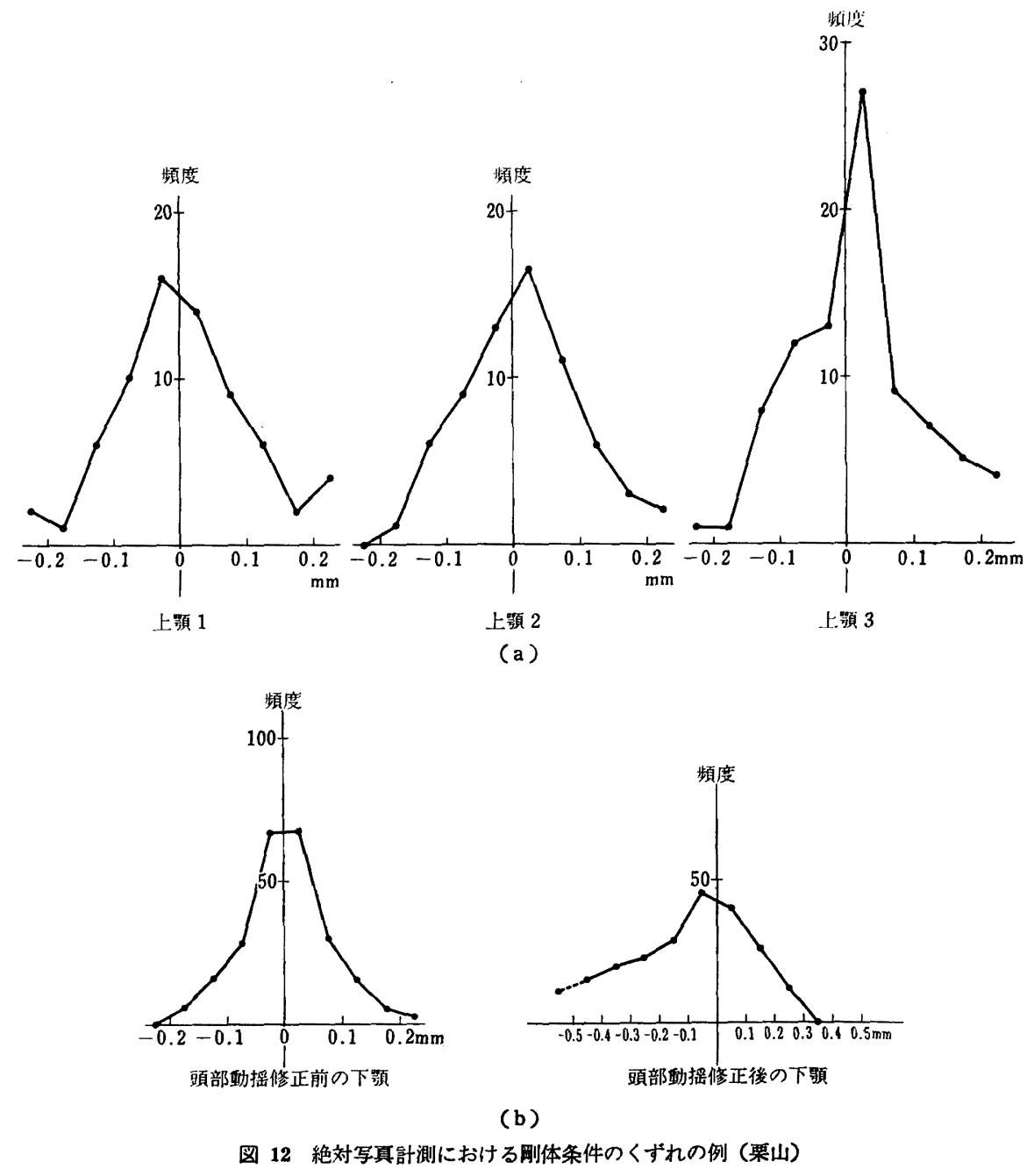


$\sqrt{\text { data (1) } \mathrm{SD}^{2}+\text { data (2) } \mathrm{SD}^{2}}$

となる.ここで, data (1) と data (2) が一様な測定誤 差をもつならば, (15)式はもとの SD の $\sqrt{2}$ 倍となる.

図 12 に示した結果は (1)頭部動摇の計算, (2)真の下頡 運動を求める計算, (3㴊体条件の検討といずれも減算処 理にあたるものである.したがって,誤差の伝搬は頭部動 播修正前については(3)で $\sqrt{\mathrm{LSD}^{2}+\mathrm{LSD}^{2}}=\sqrt{2} \mathrm{LSD}$ とな り，頭部動摇修正後につレては(1)で, $\sqrt{\mathrm{USD}^{2}+\mathrm{USD}^{2}}=$ $\sqrt{2} \mathrm{USD}$, (2)で $\sqrt{\mathrm{LSD}^{2}+2 \mathrm{USD}^{2}}$, (3)で $\sqrt{2} \cdot \sqrt{\mathrm{LSD}^{2}+}$

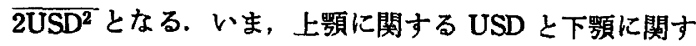
る LSD を一憡とすると, 頭部動摇修正前, 後の剖体条 件のくずれに関する誤差, 伝搬の比は $\sqrt{2}: \sqrt{6}=1$ :

$\sqrt{3}$ となる. しかし, これは理論值で図 12 では $1: 3 \sim 4$ となっている. この差異はおそらく以下のことによるも のであろう.

㣚体条件のくずれの標準偏差は上頻で $109 \mu \mathrm{m}$, 下䅡 で $72 \mu \mathrm{m}$ なので, この算出のもとである観測された各 標点の座標値の誤差の標準偏差はその $1 / \sqrt{2}$ に相当する 51〜77 $\mu \mathrm{m}$ となる. そしてこの 51〜77 $\mu \mathrm{m}$ を除いた残り の標準偏差は図 11 の較正実験の結果からみて, 較 正時 の真の值となるべき 3 次元読取顕微鏡の設定誤差などに 原因するものであろう.

なお，較正時にこの程度の位置設定誤差があったにも かかわらず，写真計測法としては高い精度が得られたの は, 多数の点から最小 2 乗法で変換式を求めたためであ る.

次にデータの処理方法についてであるが，上䪽の動き の修正の前後に扔いて下䫓標点の剛体条件の乱れは桩大 したので，各フィルムに起因する系統誤差は存在しない ことになり, 完全な重心基準剛体化処理を行らべきであ ったことになる.

標点の観測から下颛運動の解析までには先にも少し触 れたが，(1)頭部動摇の計算，(2)真の下顎運動を求める計 算，(4)下顎運動を標準形（原点あわせ）とする計算，(5) 下颚運動解析のための計算の 4 段階がある. したがっ て, 㓮体化処理を全く行わない時の誤差の伝搬は $2 \sqrt{2}$ 倍となり，完全剛体化処理を行えば，第血章，第 2 項に も述へたように各標点の観測された座標值に含まれる誤 差は $1 / \sqrt{3}$ となるので，誤差の伝搬も前者に比べて $1 / \sqrt{3}$ となる. 寸なわち, 完全䣓体化処理によって座標 值の誤差の標準偏差を約半分とすることができ，解析を 進めるために計算を行っても誤差を増大させることはな いということになる.ただし，棡体条件の乱れのチェッ クは常に 0.0 となり,このような方法で各観測值の測定
精度を検定することはできなくなる.

しかし，剛体化処理を行わなかったときの值を 1.0 と すると, 完全に剛体化处理を行えば $1 / \sqrt{3}=0.577$ とな るが, 栗山12)の顆路に関する研究に際しては, 系統誤差 の存在を恐れ，誤差 1.0 の点を 3 点と誤差 $1 / \sqrt{3}$ の点を 2 点等価に扱い最小 2 乗法で計算をすすめたので，各標 点の誤差は $\sqrt{\frac{1^{2}+1^{2}+1^{2}+(1 / \sqrt{3})^{2}+(1 / \sqrt{3})^{2}}{5}}=0.856$ という不完全なゆるい剛体化処理しか行わなかった.

標点の発光体としては現在入手可能なもののなかで可 及的に小さいものを選んだが，それでも外形は $1 \mathrm{~mm} の$ 大きさを持ち，発光部のフィラメントは不整形をしてい るため，下顎運動により標点とカメラの相対的位置が変 化すると，微小電球の被計測部位が異なってくる.この ため下頡が大きく動いたときに剛体条件のくすれが増大 する現象がみられた．これは系統的誤差であり，補正が 可能なものと考えられるが今回洼に対策はとらなかっ た. また,このことは較正時に読取顕微鏡につけた標点 と各被験者の標点の被測定部位が完全には一致していな いということでもある.

さらに上・下䅡の Face-bow をそれぞれ完全に固定す ることが難しいために生ずる誤差も認められ，咬頭嵌合 位を繰り返しとらせたときの上下頻の相対位置のずれる 現象の大部の原因となっているであろう。また Facebow に関してはそのもの自体の歪も運動時には考えら れる.

上頷の Face-bow には各カメラ毎に 3 個の標点がつい ているが，これは下䫑位の絶対測定をするための改良過 程の産物であり，最終的に実験の全体のバランスという 点からは各 1 個の合計 3 個でもよかったものである.

この計測方法では頭部動摇を消去して純粋な下頡運動 を抽出することになっているが，1枚のフィルムに数個 の下影位が撮影されている場合，上下頡標点間の対応関 倸が難しいこと，また後戻り現象などの場合に時間的関 係，つまり他のカメラのフィルムとの対応関係が難しい ことの欠点をな招残している.これを解決するためには 1 下顎位每に 1 枚のフィルムに撮影するとか, 光電変換 により電気的に処理する方法などが考えられる. しか し，光電変換によるものは写真計測法とはいいがたい し，1 下頡位，1フィルムといら方法はポラロイドフィ ルム使用の場合には不可能に近いともいえる．また，長 尺フィルムを自動送りで使用するにしてもそのデータ読 取りおよびデータ処理は大変な作業になり，理論的に は，この方法に対する改良も可能だが，実際問題として 
$106-690$

は写真撮影による下頷運動測定としてはこれでほぼ極限 にまで到達しているといえる。

測定精度については，写真計測法以外の下顎運動測定 法を含めても $0.1 \mathrm{~mm}$ 上するものが多いが，実際に論文 を詳読すると計測部位の 1 要素についてのものであった り，読取器の精度であったりすることもある.この絶対 写真計測法での精度標準偏差 $250 \mu \mathrm{m}$ という值は一見大 きく見えるが，現在歯科が関心を持っているような範囲 のどの部位に関してもこの精度であり，種々の解析処理 をしてもこれ以上に誤差を增大させないという值であ る.このような意味からは先人の測定精度よりはるかに 高いものといえる.

しかし，生体の要求する補緅物の精度 ${ }^{18)}$ 等に比べれば 必ずしも充分な値とはいえないので，写真法を利用する か否かは別問題として，なお下額運動測定の精度向上に は努力しなければならないであろう。

\section{V. 総 括}

写真計測法による 3 点 3 次元下影運動測定法を完成形 と考えられる程にまで改良することに成功したので，そ の測定装置の構成および測定方法について記述した。

また，観測値からの解析結果の精度を高めるために重 心基準剛体化処理法を提案した.

\section{文献}

1）大石司郎：フーム型運動分解器とコンデンサー法によ る下影運動の研究. 第 2 報 側方滑走運動ならびに咀噒 運動の水平面投影に関する考察。補経誌，7：196～205， 昭和38 (1963).

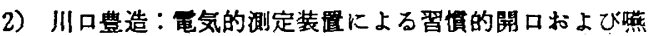
下の娄牙接触位に関する研究，補経誌，12：397〜 422, 昭和43 (1968).

3）田中伐平：ID-tracer，投稿予定，補綴誌.

4) Shoji Kohno, Eiichi Bando, Batsuhei Tanaka, Minoru Kuriyama and Tsuneo Tabata: Man- dibular Movement and Mandibular Position in Man. In Jaw position and jaw movement, edited by Kubota, K., Nakamura, Y. and Schumacher, G.H. (Eds.), VEB Verlag Volk und Gesundheit, Berlin, 1979, (in press).

5）真柳昭紘：側方滑走罣動における顆頭運動に関する研 究, 補緅誌，14:158～182，昭和45（1970）.

6) 野村莱太郎：侧方咬合位におけ子咬合器の再現性と運 動様式に閔する研究，㭪緅誌，15：239２66，昭和 46 (1971).

7）佐久間孔毅：マルチフラッシュ装貫による有歯影の前 後および開閉運動の研究，口病誌，26:1511 1536, 昭 和34 (1959).

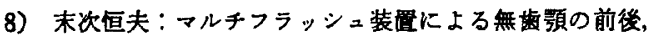
開閉運動並びに下額位の研究，補緅誌，5：131〜169, 昭和36 (1961).

9）河野正司：下額の矢状面内運動化対応する顆頭運動の 研究，第 2 報, マルチフラッシュ装貫による矢状面運動 の解析，補経誌， $12: 350 \sim 380$, 昭和43 (1968).

10）古屋良一：頻口腔系の機能に異常を有する者の下影運 動の研究，補緅誌，18:221 245, 昭和50 (1975).

11）中野雅徳：側方滑走運動における顆路と切歯路化関す 万研究, 衼経誌, $19: 461 \sim 479$, 昭和50 (1975).

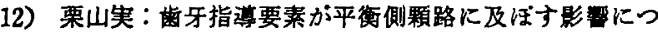
いて, 補緅誌, $23: 126 \sim 147$, 昭和54 (1979).

13）坂東永一，新井泉，古屋良一，長谷川成男，田端佰雄 下頻限界運動の図形表示による解析，補䟾誌，20： 295 303, 昭和51 (1976).

14）石原寿郎：下影運動に開する取近の研究，口病誌，30： 81 99, 昭和38 (1963).

15）福島俊士：習垻的開閉運動に括ける顆頭運動の研究，補 緅誌，15：267～290，昭和46（1971）。

16）中川徹，小柳義夫，戸川隼人：最小二乗法標準プロクララ $\triangle$ SALS (第 2 版) 利用の手引（第 1 部 基礎篇・第 2 部 制御・解法篇), 東京大学大型計算機センター, 1975，(整理番号T-3-06，T-3-07)。

17) HITAC $8700 \mathrm{MSL}:$ ブログラム・マニュフル (アブリ ケーション), 8700-7-005, 昭和47 (1972).

18）田中伐平：咬頭嵌合位に扰ける補経物の高さが影口空 系に及注寸影共，補緅誌，19(4)：480～506，昭和 51 (1976). 